Summer 2010

\title{
Introduction: Transatlantic Perspectives on Law, Security and Power: A German/American Dialogue on NATO's 60th Anniversary
}

Follow this and additional works at: https://www.repository.law.indiana.edu/ijgls

Part of the Comparative and Foreign Law Commons, European Law Commons, and the International Law Commons

\section{Recommended Citation}

(2010) "Introduction: Transatlantic Perspectives on Law, Security and Power: A German/American Dialogue on NATO's 60th Anniversary," Indiana Journal of Global Legal Studies: Vol. 17 : Iss. 2 , Article 1. Available at: https://www.repository.law.indiana.edu/ijgls/vol17/iss2/1

This Symposium is brought to you for free and open access by the Law School Journals at Digital Repository @ Maurer Law. It has been accepted for inclusion in Indiana Journal of Global Legal Studies by an authorized editor of Digital Repository @ Maurer Law. For more information, please contact rvaughan@indiana.edu.

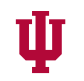

JEROME HALL LAW LIBRARY

INDIANA UNIVERSITY Maurer School of Law
Blooming ton 


\section{Introduction}

\section{Transatlantic Perspectives on Law, Security and Power: A German/American Dialogue on NATO's 60th Anniversary}

Since the end of the Cold War, NATO has been mired in existential crisis. This is not to say that it has become irrelevant: it experienced a dramatic expansion of membership in the 1990s that continues today. In addition, events following the terrorist attacks of September 11, 2001 , including the first-ever invocation of NATO's article 5 collective security mechanism, signaled at least the possibility of meaningful accord. The end of the Bush Administration too carried some promise for NATO's trans-atlanticism, especially with Barack Obama making hope and dialogue centerpieces of the foreign policy platform that launched his presidency.

Yet NATO continues to struggle to justify itself, as the 60th anniversary summit of last spring demonstrated so clearly. The run-up to that summit revealed some major fault lines. Many American policymakers view NATO as a bureaucratic bog from which Europeans extract their security without having to get their own feet wet. Europeans, on the other hand, are likelier to view NATO as the last vestige of America's Cold War primacy. Disagreement exists also on the fundamental question of how best to advance geopolitical interests today-as reflected in the observation of one editorialist that "NATO and the United States do hard power, the European Union does soft power."

The run-up to the summit also revealed consensus that Afghanistan is emerging as the test of NATO's staying power. And on that count, the result of the summit invites speculation about NATO's future.

In an editorial published immediately prior to the summit, entitled "NATO at 60: Alive and Kicking," NATO's Secretary General offered a

1. Stanley R. Sloan, Editorial, Pondering NATO's Future, N.Y. TIMES, March 4, 2009, available at http://www.nytimes.com/2009/03/05/opinion/05iht-edsloan.4.20621814.html.

Indiana Journal of Global Legal Studies Vol. 17 \#2 (Summer 2010)

(C) Indiana University Maurer School of Law

DOI: 10.2979/GLS.2010.17.2.183 
hopeful perspective:

Security is not a discretionary item, something you can live without when money is tight. It is the foundation on which our prosperity is built. And, like the economy, security can only be built through multinational cooperation. This is why the NATO summit is more than a celebration; it is a meeting where alliance leaders need to get things done.

First and foremost, they will have to chart a common way forward on Afghanistan ....

NATO is alive and kicking because it still has a unique job to do: to be the place where Europe and North America stand together, consult together and act together to ensure their common security. That role will be reaffirmed and strengthened at this weekend's summit. $^{2}$

But that sense of optimism was absent in a report published immediately afterwards:

NATO leaders . . . gave a tepid troop commitment to President Obama's escalating campaign in Afghanistan, mostly committing soldiers only to a temporary security duty....

Despite a glowing reception and widespread praise for Mr. Obama's style and aims, his calls for a more lasting European troop increase for Afghanistan were politely brushed aside. ${ }^{3}$

With this as background, the contributors to this discussion will offer transatlantic perspectives on security and power, focusing in particular on how law both conditions the exercise of power and reveals the deeply contextual underpinnings of different approaches to security.

2. Jaap de Hoop Scheffer, Op-Ed., NATO at 60: Alive and Kicking, N.Y. TMmes, Apr. 2, 2009, available at http:/www.nytimes.com/2009/04/03/opinion/03iht-edscheffer.html.

3. Steven Erlanger \& Helene Cooper, Europeans Offer Few New Troops for Afghanistan, N.Y. TTMES, Apr. 4, 2009, available at http://www.nytimes.com/2009/ 04/05/world/europe/05prexy.html. 
In her essay "NATO at Sixty: America Between Law and War," Mary Ellen O'Connell focuses on the U.S. perspective on law and the projection of power. According to Professor O'Connell, "a very different world still has NATO because of an American need for military power." But, she argues, "Americans could change. They could move back again to emphasizing preference for law. The United States could, once again, be the champion of peace through law."

The second contributor, Russell Miller, analyzes Germany's postwar constitutional jurisprudence and its meaning for the use of force. ${ }^{7}$ Based on this analysis he questions "the realism that dominates U.S. international law and international relations theory and practice," concluding that "[w]hen it comes to force, the law is far from dead."

Elisabeth Zoller, the final contributor to this symposium, offers "Two Concluding Remarks"10 in response to the contributions of Miller and O'Connell. She notes that both authors "pursue a common theme in American legal thinking-peace through law."11 She argues, however, that Professor O'Connell's "clear solution" is precluded for "[b]oth legal and factual reasons." 12 She provides an alternative perspective, concluding that although NATO "is not per se the realization of the ideal of peace through law, ... . it makes it possible to take steps toward that goal."13
4. 17 IND. J. Global LeGAL STUD. 187 (2010).
5. Id. at 195 .
6. Id. at 196 .
7. 17 IND. J. GLOBAL LEGaL STUD. 197 (2010).
8. Id. at 205.
9. Id. at 206 (internal citation omitted).
10. 17 IND. J. GLOBAL LEGAL STUD. 207 (2010).
11. Id. at 207.
12. Id. at 208 .
13. Id. at 209. 
